\title{
5 Theology Without Walls as the quest for interreligious wisdom
}

\author{
John J. Thatamanil
}

Theology Without Walls (TWW) is not a single, highly integrated, and uniform research program but rather a family of kindred research projects. As TWW gains greater traction and more voices join in, the methodological diversity within TWW will only continue to expand. What binds these diverse projects together is the core conviction that theological truth is available, and therefore must be pursued, beyond the walls of any single religion. If there is (at least one) ultimate reality, there is no reason to suspect confessional claims notwithstanding - that ultimate reality is accessible through a single tradition alone. Indeed, even exclusivist confessional thinkers typically insist that knowledge of God, even if to an inferior degree, is available to those outside the tradition, for example, in the book of nature and not just in the book of scripture. If such truth is, indeed, available, and if what is so available does not replicate what is already known within a single tradition, then theologians must commend investment in transreligious learning.

TWW investigators may seek knowledge of ultimate reality in literature, in the work of scientific cosmologists and evolutionary biologists, in comparative theology, or by way of experimentation with mind-altering psilocybin. Ultimate reality cannot be corralled within the boundaries of those domains of cultural life that some modern communities have taken to calling "the religions." What sort of self-respecting ultimate reality would that be? Speaking in traditional Christian theological terms, as God is the God of the whole world, traces of divinity will be found anywhere one thinks to look. Hence, a diversity of approaches and methods is inevitable for TWW.

In this chapter, I propose one particular conception of TWW that has for its goal interreligious wisdom gained by means of engagement with not just the claims of other traditions but also their ends and the means to those ends. I hold that at least some who engage in TWW will do so by way of multiple religious participation, that is by taking up practices drawn from the repertoire of more than one religious tradition, practices that provide access to the spiritual ends prized by the traditions in question. In what follows, I offer a rudimentary sketch of this version of TWW, commend its desirability and importance, and describe some of the unique conceptual and practical challenges that come with it. I have no intention of commending 
its superiority to other modes of TWW. Not all will be drawn to the appeals and demands of this style of theological engagement. Nonetheless, I commend this account of TWW because it affords access to what I call interreligious wisdom, first-order knowledge of ultimate reality gained by drawing from the resources of more than one religious tradition.

\section{Theology is more than making claims: on theological ends and means}

Theological reflection within many contemporary forms of Christianity remains a resolutely cognitivist enterprise wedded to the labor of making and assessing claims about God and God's relation to the world and human beings. ${ }^{1}$ There is nothing misguided about such a project. Theological work quite naturally seeks to think about how best to construe ultimacy. Is God a being among beings or rather the ground of being? Is ultimate reality personal, transpersonal, or perhaps even both in different respects? Is the relation between ultimacy and the world best understood within a pantheist, panentheistic, nondualist, or dualist metaphysics? Of course, these questions might also be taken up within the framework of philosophy of religion. What customarily renders these questions distinctively theological is the constraint that they are taken up with reference to the sources and norms of a particular tradition, a constraint that TWW rejects.

Might we entertain another conception of what makes thinking theological, a conception that hinges not on exclusivity - "Work within the parameters of this tradition alone!" - but instead understands theology as marked by existential commitment to the pursuit of religious truth gained through the theologian's own transformation, a transformation brought about by taking up the spiritual disciplines that serve as the means for reaching the distinctive spiritual ends of the tradition in question? True, Pierre Hadot has shown that within the history of the West, philosophy, too, was once understood to require spiritual discipline, but this particular conception of philosophy has largely fallen by the wayside (Hadot 1995). In this historical moment, theology seems better suited as the rubric for committed truth seeking gained through spiritual transformation.

Such theology would be attentive to far more than theological claim assessment but would instead seek to understand claims within the broader spiritual matrix from which they are often isolated for the sake of deliberation. Even within Christian circles, theology has not always been focused on claims to the exclusion of religious ends and the means by which those ends were reached. Recall one of the tradition's earliest definitions of the theologian by the fourth-century desert father, Evagrius: "The one who prays truly is the theologian; the theologian is one who prays truly" (Ponticus 1972, 65). For Evagrius, prayer makes the theologian, not the proposal and defense of this or that set of theological claims. The theologian is one who comes to intimate knowledge of the divine by means of the spiritual 
discipline of prayer, which is itself a gift of God. The theologian is the one who knows God, not merely knows about God. This knowledge of rather than knowledge about is driven by soteriological desire. The end of Christian life is knowledge, and love of God that sets human beings free from sin, death, and the devil, and that knowledge is to be gained by means of the spiritual discipline of prayer.

In the kind of TWW I am proposing herein, the theologian rejects denominational or traditional exclusivity but embraces Evagrius's insistence on the centrality of the religious means that aim at transformative truth. Evagrius's maxim reminds us that ancient Christian traditions affirmed an intimate and inseparable bond between religious ends and the means by which those ends are attained. The theologian's vocation and identity are secured, within such a framework, by commitment to spiritual disciplines and not by way of conceptual assessment alone.

What if, borrowing from and riffing on Evagrius, we proposed the following contemporary maxim: the interreligious theologian is one who prays and meditates truly; the one who prays and meditates truly is the interreligious theologian. Here, of course, "meditation" is a placeholder, a token for some specific set of disciplines for religious knowing commended by a nonChristian tradition. Theologians without walls, in my account, are those who seek to know ultimate reality not by rejecting the spiritual disciplines of their home tradition but by supplementing those disciplines with others responsibly borrowed from another tradition. Actually, this provisional definition needs further nuance because there is no reason to assume, from the first, that the theologian without walls has a single home tradition, let alone the Christian one. Religious affiliations, in our time, defy any predictable pattern. A theologian without walls or the transrreligious theologian is one who seeks to know the truth of ultimate reality by faithfully engaging in the spiritual disciplines of more than one religious tradition.

\section{Some key terms, definitions, and operative assumptions}

What are the fundamental assumptions that render such a definition of transreligious theology meaningful and desirable? I would like to lay out here a number of central terms, definitions, and operative assumptions that I bring to the work of transreligious theology. To begin with the basics, just what do we mean by the terms "religious" and "religions?" How can care with definitions correct for the doctrinal preoccupations of much contemporary theology? How can we strive to ensure that our definitions of religion do not build into themselves expectations that render singular religious belonging normative and multiple religious participation aberrant?

To be religious, in my account, is to search for comprehensive qualitative orientation. Religious persons and communities seek to take their place with respect to the whole of things, the nature of reality as such, in an affective key. Religious orientation, as opposed to, say, scientific orientation, seeks 
to order buman desiring such that human desires are rendered true to the nature of reality. How should human desiring be ordered if reality is marked by impermanence and insubstantiality? What if, beyond all the finite goods given in experience, there is an infinite good upon whom all finite things depend? What would that entail for how desire is ordered? If reality is marked by radical interdependence, such that my well-being is inseparable from yours, then what should I do about deeply entrenched habits of selfseeking that presently mar my life with others? What are we to do about market-based regimes of shaping desire that teach that the collective good spontaneously emerges by maximizing individualistic acquisitive impulses? All of these questions about what to do with our desiring, when desires are situated within some account of the way things are, count as religious.

Nothing about this project to render human desiring true to the real implies an understanding of the religious as passive rather than activist in character. In order to render human desiring true to the nature of the real as such, one might well have to undo social orders that are marked by falsity, triviality, and destructivity. Religious comportment can and routinely does take on the work of world transformation.

The religious work of orienting desire within a cosmic frame has historically taken place within local and translocal communities whose lives have been shaped by a variety of traditions that we have taken recently to calling "religions" or "world religions." In much of the globe for much of human history, any given local community was informed by a variety of religious traditions. That such religious diversity marked East Asian and South Asian life is well known. Less well known is the presence of enduring multiplicity in "Christian lands." The presence of various indigenous and pagan customs and practices has diversely colored the Christianities of Ireland, Brazil, and even Italy. That is why even European Christianities have distinctive local flavors, flavors as distinctive as their respective cuisines. The work of comprehensive qualitative orientation thus routinely draws upon the repertoires of more than one religious tradition.

Religious traditions are historically deep repertoires of myths, rituals, practices, symbols, sacred objects, sacred sites, scriptures, institutions, norms, experiences, and intuitions. More precisely, traditions are arguments about what ought to be in a given tradition's repertoire and how that repertoire ought to be employed in the work of generating interpretive schemes and therapeutic regimes. Interpretive schemes are the means by which religious thinkers and their communities give an account of the nature of reality. Therapeutic regimes are the means by which personal and communal desiring is attuned to the nature of the real as depicted by an interpretive scheme. Therapeutic regimes include rituals, practices of worship, spiritual exercises, pilgrimages, and the like by which personal and communal lives are tutored and shaped so as to be rendered true to and true for the real.

Religious traditions are not interpretive schemes; they contain a plethora of interpretive schemes, and theologians, both elite and lay, continue 
to generate and debate a host of interpretive schemes. There is neither a single Christian nor Buddhist take on reality. There are historically fluid and geographically diverse Christian and Buddhist repertoires, which are then deployed in contested fashion by religious intellectuals and their communities.

The ingredients contained within a given religious repertoire are malleable and constantly subject to growth and subtraction, but not infinitely so. Certain items have historic staying power and come to be seen as essential to that repertoire because of symbolic power, entrenched habit, the backing of institutional elites, sheer antiquity, and a host of other reasons. It is just as difficult to imagine a Christian interpretive scheme that does not make use of the cross, baptism, or some account of the resurrection as it would be to imagine South Indian cuisine without cumin, coriander, turmeric, mustard seeds, or coconut milk. Not every ingredient is found in all curries, but there are recognizable continuities. Likewise, not every ingredient from the Christian repertoire is found in any particular Christian theological vision, but there are recognizable continuities that mark a Christian dish as Christian or a Buddhist dish as Buddhist. It is difficult to imagine a Christian therapeutic regime that takes leave altogether of prayer of some kind (intercessory, contemplative, etc.), although even so "central" an ingredient as the Eucharist is relatively marginal in some ecclesial families.

Not every Buddhist meditates or chants mantras - there is a vast difference between monastic and lay practice, for example - but, again, one recognizes important material historical continuities. A theory of the religious traditions must strike the right balance between continuity and creativity, a task well beyond the scope of this chapter. Emphasize continuity alone, and agency is stripped from religious actors; emphasize creativity alone, and the historical depth, heft, and binding power of traditions might be forgotten.

The appeal to the example of cooking in this context is not random. No two Kerala fish curries are identical, even when prepared by members of a single family. But you do generally know when you are having a Kerala fish curry. If the dish doesn't have some combination of tamarind, coconut milk, mustard seeds, curry leaves, turmeric, garlic, and a good many chilies, what you've concocted may taste good, but it is unlikely to be a Kerala fish curry. Tradition imposes constraints, but those constraints can themselves serve as the material basis for improvisational creativity.

For the purposes of this chapter, what must be reemphasized is that the work of comprehensive qualitative orientation cannot be accomplished by appeal to an interpretive scheme alone, no more than reading the ingredients from a recipe will satisfy hunger. Desires are configured in healing and lifegiving fashion when they are shaped by means of the specific spiritual disciplines that enable human beings to accomplish the religious ends celebrated by the tradition in question. Human flourishing requires truing oneself to the nature of the real; religious orientation is, hence, a matter of comportment, when desires are in right accord with the reality rightly interpreted. 
For most religious traditions, right comportment requires that human beings are rightly attuned to certain feature or features of reality that are taken to be ultimate. I speak of "features" in this context rather than a singular ultimate reality because it is not clear that all religious traditions maintain that a single ultimate reality exists. A given tradition might celebrate a plurality of Orishas or instead point to the fact that everything in reality whatsoever is empty (sunya) of self-existence (svabhava). The former is not a singular ultimate, and the latter is not easily characterized as an ultimate reality in the way that either God or Brahman might be.

Comportment requires that human beings are in right accord with ultimacy rather than merely know about ultimacy. Here, one might speak about first-order knowledge, knowledge of, rather than second-order knowledge, knowledge about. Consider, for example, the knowledge that Michael Phelps has of water as opposed to the nonswimmer who happens to be expert in fluid mechanics. The latter knows a very great deal about water, far more than Phelps, in fact, but as a nonswimmer, she would not be long for the world if she should happen to fall into the deep end of a pool.

First-order religious knowing, the kind that Evagrius commends, is acquired only by means of spiritual disciplines such as prayer and meditation. Without proper comportment, there is no true knowledge of the real. This is why generations of students in the nation's "Introduction to Buddhism" classes have not spontaneously awakened to wisdom upon a first hearing or reading of the Four Noble Truths. Enlightenment experiences are not recurring features of collegiate lecture halls even when staffed by brilliant lecturers. Reading the recipe is not cooking, let alone eating the dish.

Buddhist traditions customarily insist on the priority of spiritual disciplines. Zen students do not receive lectures on Dogen but are instead compelled to sit in Zazen. What there is to know about Zen is learned, first and foremost, by taking on a particular therapeutic regime that tutors the body to see as Zen what teachers want the student to see. Even dharma talks are not so much about the transmission of doctrinal or propositional information but are instead meant to elicit and evoke transformation. The upshot: if you want to know as Buddhists know, you must do as Buddhists do. There are no shortcuts.

\section{Multiple religious participation as the precondition for interreligious wisdom}

With these preliminary terms and definitions in place, we are now able to say just why multiple religious participation is necessary for one modality of TWW, namely that which strives at interreligious wisdom. But first, one additional definition is necessary, that of interreligious wisdom. Religious traditions account persons to be wise when they have, by means of right comportment, arrived at embodied knowing of ultimate reality as understood by the tradition in question. Persons are recognized to be wise when 
they have arrived at intimate first-order knowledge of ultimate reality by means of spiritual disciplines that have rightly attuned human desiring. It would follow that interreligious wisdom arises when human beings come into an embodied knowing of reality as understood by means of the therapeutic regimes of more than one tradition. In so doing, these persons will have inscribed into their bodies first-order knowledge of ultimate reality or ultimate features of reality as articulated by the interpretative schemes of traditions whose therapeutic regimes they have taken up. I have elsewhere spoken of such wisdom as a kind of binocular vision - the capacity to see the world through more than one set of religious lenses and to integrate what is seen thereby. I wish to argue that at least some theologians without walls must set themselves to the pursuit of such binocular vision by way of multiple religious participation.

But is such interreligious wisdom possible? What are the conditions for the possibility of such wisdom? And, if possible, is it desirable? What obstacles, if any, stand in the way of such wisdom? Who might interreligious wisdom be for? What communities might it serve? These are the questions that I take up in the remainder of this chapter. Let's address these questions in turn.

Proof of actuality is, of course, proof of possibility. We know that interreligious wisdom is possible precisely because we know of a host of religious luminaries who have successfully committed themselves to the cultivation of such wisdom. Consider, for example, Buddhist-Christian figures such as Ruben Habito, Maria Reis Habito, Sallie King, and Paul Knitter. ${ }^{2}$ These thinkers are, in each case, not merely speculative students of Buddhist and Christian interpretive schemes considered in isolation from Buddhist therapeutic regimes. Each is grounded in years, even decades, of multiple religious participation, with recognized teachers in Buddhist traditions. In the case of Ruben Habito, his immersion in Buddhist practice is so thoroughgoing that he has received dharma transmission and is now a Buddhist teacher within a Zen lineage while remaining a Christian. These figures are Christians who have remained Christian even as they came to be deeply steeped in Buddhist traditions.

On the Hindu-Christian front, one can readily think of figures such as Raimon Panikkar, Swami Abhishiktananda, and Bede Griffiths, among others. ${ }^{3}$ Particularly in the case of Abhishiktananada and Bede Griffiths, we have figures who immersed themselves in contemplative practice in the Advaitic strand of Hindu traditions. Their theological writings followed only after taking up the contemplative therapeutic regimen of Advaita Vedanta. The goal of such writing is to integrate, so far as possible, nondual wisdom with Christian devotional practice and wisdom, a meeting between wisdoms that takes place in "the cave of the heart." Questions about the Christian trinity and nonduality are taken up as they are illumined by the interspiritual experiences generated by practice and are not driven solely by a penchant for speculative theological ontology. The quest for such integration has to it an experiential 
intensity and rigor that, at least in the case of Abhishiktananda, proved to be soul-wrenching. It is no simple matter to integrate into one's life experience the competing appeals of nondualism and devotionalism when both have had an integral place within one's own spiritual life and orientation. ${ }^{4}$

No treatment of what these figures have come to know about ultimacy is possible herein, but a careful study of them would be an integral component in a research program that sought to think through the nature and possibilities for interreligious wisdom. What have such figures learned? What challenges have they faced? What is the relationship between their interreligious wisdom and wisdom as conventionally understood by each of the single traditions to which these figures made appeal? Such research would, I suspect, not just show that interreligious wisdom is a meaningful notion but also go a considerable way toward elucidating what interreligious wisdom is.

Let us turn now to the question, "What are the conditions for the possibility of interreligious wisdom, and why might such wisdom be desirable?" To answer that question, I posit the following propositions:

1 What we know of ultimate reality is intimately tied to how we come to know ultimate reality. The knower must become transformed so as to come into a knowing of ultimate reality in the respect that the seeker seeks to know it.

2 Ultimate reality is a multiplicity, not an undifferentiated simplicity.

3 Therefore, it follows that if different dimensions of the ultimate reality are to be known, they must be accessed by means of the specific spiritual disciplines that afford such access.

4 The bearer of interreligious wisdom, therefore, is one who has come to know more than one dimension of ultimate reality and has begun to integrate what has been so learned.

Interreligious wisdom is possible if these propositions hold.

First, we have already argued that first-order knowing of ultimate reality can be gained by means of the specific disciplines, the therapeutic regimes that make just such knowledge possible. Just as Michael Phelps undertakes the specific training regimens that create in his body the complex habitus that makes possible excellence in swimming, so, too, those who seek to know ultimate reality - not merely know about ultimate reality - must undertake specific disciplines. If no such disciplines exist, then there is no comportment to ultimate reality.

With that basic first presupposition in place, the possibility of interreligious wisdom requires the second supposition: that ultimate reality is a multiplicity and not just an undifferentiated simplicity. ${ }^{5}$ Without that hypothesis, there is no reason to suppose that the various distinct disciplines of our religious traditions can augment and enrich knowledge gained by some primary practice. There must be more dimensions to the divine life that can be diversely accessed through diverse disciplines. 
One other logical counterpossibility must be broached, namely that our various spiritual disciplines may be reduplicative. Remaining with the analogy of the swimmer, one might argue that nothing new is learned about water when a swimmer masters, in turn, the backstroke, the butterfly, and the breaststroke. What gain there is rests in the swimmer's fitness as different muscle groups are mobilized by way of these different strokes, but no new knowledge of water is gained. Water just is water. By extension, one might suggest that Zen practice grants no new knowledge of ultimacy that the Eucharist does not. The practitioner is spiritually fitter but has learned nothing more by spiritual cross-training.

This possibility must be entertained as a hypothesis, but if it holds without exception for all spiritual disciplines, then I do not see how a robust conception of interreligious wisdom can be defended. The different therapeutic regimes of our traditions would open no new vistas of vision, and the connection between religious means and the noetic ends that those means strive to access would be severed. In this account, the various spiritual disciplines would all be reduplicative, all paths up the same mountain but affording no new knowledge of it. The variety of disciplines may just be attributed to the contingent cultural-linguistic matrices from which the disciplines arise and yield no distinctive truth-bearing power.

Now, although it is certainly true that spiritual cross-training may well generate in practitioners a variety of spiritual excellences that are not directly tied to distinct dimensions of the divine life, there is every reason to believe that at least some disciplines are so connected. Some so shape persons and communities that distinctive insights are gained by means of diverse practices. We have reason to believe this because the traditions themselves tell us so. Christian life requires becoming the Kingdom-bringing egalitarian social body of the Christ. If you seek to become that body, you must eat that body's food; you must participate in the egalitarian sharing of the one bread and one cup, where Christians, in all their differences, come together and become one community of reconciled love-in-difference. In so doing, Christians become the Love that they are called to be. The discipline of Dzogchen, by contrast, is meant and employed for other purposes. The practice calls practitioners into recognition of the nature of mind itself as nondual, marked by spacelike clarity, unbounded, and intrinsically compassionate. Practice stabilizes in the practitioner this truth about their own nature; moreover, there is an inseparable connection between path and goal. What one practices is what one comes to know.

Those who seek interreligious wisdom need not posit that the practice of Eucharist and its goal are identical with the practice and goal of Dzogchen. Such assertions seem both implausible and unnecessary. Dzogchen practice operates within another ontological imaginary, one grounded in affirmation of the Buddha-nature of all beings and so operates within a different horizon of intelligibility. And it is precisely that difference which lends it desirability for some Christian practitioners. Indeed, one can only affirm the 
possibility of complementarity if one refuses to posit sameness - one must if interreligious wisdom is to be a cherished goal.

Christian Eucharistic practice, by contrast, is not rooted in nondual metaphysical commitments. Difference matters. The uniqueness of the many gathered is affirmed in the singularity of each one, a singularity that is drawn without reduction or elimination into relation and community. And, of course and most obviously, the Eucharist is an act of worship of One who is not in every sense identical to those who worship. Here, of course, it is all too easy to become ontologically reductive. Christian theologies of God are all, without exception, aware that God is not a finite and countable object. To affirm that God is infinite is immediately to complicate every conventional depiction of the God-world relation as flatly akin to the relation between finite objects.

One need only remember, for example, Nicholas of Cusa's insistence that God is best understood as non-aliud, Not-Other, to realize that Christian theological imagination cannot be narrowly confined to a dialogical frame that is taken precisely to mirror dialogue as it takes place between two human interlocutors. Beginning with St. Paul, Christians have affirmed that the "dialogical structure" of prayer is most peculiar. "Likewise the Spirit helps us in our weakness; for we do not know how to pray as we ought, but that very Spirit intercedes with sighs too deep for words" (Rom 8:26: NRSV). God prays to God in and through us; this is surely not dialogue as usual. Still, devotional life is marked by a longing for One who is not just or simply me, even if my longing for God is always already God's longing in me.

With these differences between Eucharist and Dzogchen sketched, albeit hastily, we are able to posit that the transreligious theologian might take up both practices with faithfulness, integrity, and some enduring continuity so as to be formed in depth by both practices and the matrices within which those practices are embedded. The wager is that differences matter, that there is an intimate noetic relation between the practices and what they seek to illuminate, and that each grants access to dimensions of ultimate reality that the other does not. The questions guiding the transreligious theologian might include these: 1) Might there be dimensions of ultimate reality that correlate to the nondualism of Dzogchen and the complicated logic of singularity and relation present in Eucharist? 2) Might ultimate reality contain dimensions that are, on the one hand, nondually related to world and self and also dimensions that cannot be characterized as nondual and might even be meaningfully encountered as personal? 3) If so, how might one become maximally attuned, insofar as possible, to both dimensions and features of ultimate reality? 4) What kind of theological living and writing might follow from such transreligious living?

These questions, when taken together, point to the novelty and promise of transreligious theology as a quest for interreligious wisdom. What is sought is a practical braiding of spiritual disciplines, first, in the life of the practitioner and only then in the writing and teaching that might flow from such a 
life. Textual writing follows only after a writing into a flesh of the therapeutic regimes of specific traditions, which creates in the practitioner the long training that opens angles of vision that cannot be opened otherwise. The practitioner's primary goal is to arrive at a "sense and taste" for dimensions of ultimate reality by means of just these practices and then just this second set of practices. First-order intimacy is the cherished goal. The transformed theologian is the first product of transreligious theology imagined in this practical key; textual production follows next as an expression of what has been so learned.

\section{Notes}

1 The charge against a narrowly cognitivist-propositional account of theology was perhaps most famously made in contemporary theology by George Lindbeck in his brilliantly argued, The Nature of Doctrine: Religion and Theology in a Postliberal Age (1984). My project is unlikely to be mistaken for his, but we do share a conviction that theological life is embedded within larger cultural-linguistic milieus. But there agreement ends. With other thinkers, most especially Kathryn Tanner in Theories of Culture, I reject the notion that religious traditions are unitary, tightly integrated, cultural-linguistic schemes with transhistorically enduring deep grammars. There are no nonporous boundaries between Christian metanarratives and non-Christian language games anywhere to be found because they do not exist. Human beings, Christians being no exception, live at the intersection of and navigate between multiple porous traditions, sacred and secular. We are, all of us, always already multiple; the question is only whether we are intentionally or accidentally so. On all these matters, it is impossible to exceed Tanner's work. See Tanner (1997).

2 For a discussion of these exemplary dual belongers, see Drew (2011).

3 For more about these figures, see Ulrich (2011) and (2004)

4 For a brief but illuminating account of the intensity of Swamiji's struggle, see Amaladoss (2016).

5 There is, of course, also the possibility that there may be more than one ultimate reality. This option has been proposed by a variety of thinkers, including, most prominently, David Ray Griffin and John Cobb. Griffin also points to Mark Heim as a kindred spirit and ally. For Griffin and Cobb, there are at least three: God, a personal ultimate; creativity, a transpersonal ultimate; and the world itself. Together, these three can account for personal religious experience, the transpersonal experiences of Hindu and Buddhist traditions, and the cosmic/naturalistic religiosities. See Griffin (2005).

\section{References}

Amaladoss, Michael. 2016. "Being Hindu-Christian: A Play of Interpretations - The Experience of Swami Abhishiktananda," pp. 89-98, in Many Yet One? Multiple Religious Belonging, edited by Peniel Jesudason, Rufus Rajkumar, and Joseph Prabhakar Dayam. Geneva: World Council of Churches.

Drew, Rose. 2011. Buddhist and Christian? An Exploration of Dual Belonging. New York: Routledge.

Griffin, David R., ed. 2005. Deep Religious Pluralism. Louisville: Westminster John Knox. 
Hadot, Pierre. 1995. Philosophy as a Way of Life: Philosophical Exercises from Socrates to Foucault. Malden, MA: Blackwell.

Lindbeck, George. 1984. The Nature of Doctrine: Religion and Theology in a Postliberal Age. Louisville: Westminster John Knox.

Ponticus, Evagrius. 1972. Evagrius Ponticus: The Praktikos. Chapters on Prayer. Kalamazoo, MI: Cistercian Publications.

Tanner, Kathryn. 1997. Theories of Culture: A New Agenda for Theology. Minneapolis: Fortress Press.

Ulrich, Edward T. 2004. "Swami Abhishiktananda and Comparative Theology." Horizons 31 (1): 40-63. doi:10.1017/s0360966900001067

Ulrich, Edward T. 2011. "Convergences and Divergences: The Lives of Swami Abhishiktananda and Raimundo Panikkar." Journal of Hindu-Christian Studies 24: 36-45. doi:10.7825/2164-6279.1486 